\title{
EKSPLORASI KESEJAHTERAAN PSIKOLOGIS INDIVIDU DEWASA AWAL PENYANDANG TUNANETRA
}

\author{
Mega Tala Harimukthi, Kartika Sari Dewi*
}

Fakultas Psikologi Universitas Diponegoro

J1. Prof. Sudharto SH, Tembalang, Semarang 50275

*ksdewi.pklinis@gmail.com

\begin{abstract}
This study aims to explore the psychological well-being of individuals who were blind in early adulthood (late blind), particularly to understand the changes and the antecedents of their psychological well-being. Two adults, aged 20-40 years, who were blind in early adulthood, had participated in this study. This is a qualitative phenomenological study. Data were analyzed using the interpretative phenomenological analysis (IPA). The results showed that late blind brought several impacts on subjects. Both subjects identified a decreased communication skill, a reduced movement ability, and negative emotional response in the beginning of blindness as the antecedents of their psychological well-being. The increased of psychological well-being was obtained due to social support -in terms of emotional, informational, and instrumental support- from family, partner, friends, and community. Although both subjects applied different coping strategies, they both reported an increased psychological well-being after they reached self-acceptance dimension. This study revealed selfacceptance as initial dimension that helped subjects to reach other dimensions of psychological well-being: life goals, independence, environment mastery, personal growth, and positive relationships with others.
\end{abstract}

Keywords: psychological well-being, blind, late blind, interpretative phenomenological analysis (IPA)

\begin{abstract}
Abstrak
Penelitian ini bertujuan mengeksplorasi kesejahteraan psikologis pada individu yang menjadi tunanetra di usia dewasa awal, dan secara khusus berupaya memahami perubahan dan anteseden dari kesejahteraan psikologis mereka. Subjek penelitian adalah dua orang berusia 20-40 tahun yangmengalami kebutaan di usia dewasa awal. Penelitian ini adalah penelitian kualitatif yang menggunakan pendekatan fenomenologi. Data yang diperoleh dianalisis menggunakan metode interpretative phenomenological analysis (IPA). Kesejahteraan psikologis semua subjek mengalami perubahan akibat kebutaan yang dialaminya ketika usia dewasa awal. Di awal munculnya gejala, menurunnya kemampuan berkomunikasi, penurunan kemampuan mobilisasi, dan respon emosi negatif diungkap semua subjek sebagai anteseden menurunnya kesejahteraan psikologis mereka. Sedangkan peningkatan kesejahteraan psikologisdisebabkan oleh adanya dukungan sosial berupa dukungan emosi, informasi, dan instrumental yang bersumber dari keluarga, pasangan, teman, dan kelompok. Meskipun keduanya memiliki strategi coping yang berbeda, namun peningkatan kesejahteraan psikologis dapat dirasakan keduanya, setelah dimensi penerimaan diri berhasil diraihnya. Yang menarik adalah terungkapnya dimensi penerimaan diri sebagai dimensi awal yang membantu subjek dalam mencapai dimensi-dimensi kesejahteraan psikologis yang lain, yaitu tujuan hidup, kemandirian, penguasaan lingkungan, pertumbuhan personal, dan hubungan positif dengan orang lain.
\end{abstract}

Kata kunci: kesejahteraan psikologis, tunanetra, dewasa awal, analisis interpretatif fenomenologis

\section{PENDAHULUAN}
Menurut World Health Organization
(WHO), pada tahun 2009 sekitar 314 juta

jiwa di seluruh dunia mengalami gangguan penglihatan dengan 45 juta jiwa mengalami kebutaan atau tunanetra (Zeeshan \& Aslam, 2013). Masalah kebutaan yang terjadi di 
Indonesia lebih banyak dialami oleh individu dewasa. Berbagai penyakit yang menyebabkan tingginya angka kebutaan di Indonesia, antara lain katarak $(0,78 \%)$, glukoma $(0,20 \%)$, kelainan refraksi $(0,14 \%)$, sedangkan sisanya akibat penyakit kornea $(0,10 \%)$, retina $(0,13 \%)$, dan kekurangan vitamin A (xeroftalmia). Berdasarkan hasil survei kesehatan tahun 2008, Indonesia memiliki prosentase kebutaan sebesar $0,9 \%$ dan termasuk negara yang memiliki angka kebutaan karena katarak terbesar se-Asia Tenggara (Anna, 2011).

Sardegna (2002) menjelaskan bahwa tunanetra adalah individu yang kehilangan penglihatan karena kedua indera penglihatannya tidak berfungsi seperti orang awas. Tunanetra dibagi menjadi dua, yaitu buta (totally blind) dan low vision. Pada umumnya individu tunanetra juga memiliki hambatan dalam menerima informasi. Individu tunanetra tidak memiliki kendali yang sama terhadap lingkungan dan diri sendiri, seperti halnya yang dilakukan oleh individu awas. Keterbatasan tersebut dimungkinkan menghambat tugas-tugas perkembangannya (Delphie, 2006).

Permasalahan utama yang dialami individu yang mengalami tunanetra di usia dewasa awal terkait dengan ketidakmampuan untuk bekerja dan hidup produktif, memperoleh pasangan hidup, diasingkan, dan akan selalu bergantung pada orang lain. Dampak lain dari hilangnya penglihatan pada individu dewasa awal adalah perasaan kehilangan kemampuan untuk mengikuti aturan sosial yang berlaku di masyarakat (Crews \& Campbell, 2004). Ketakutan menghadapi kehidupan masa depan berkaitan dengan ketersediaan lapangan pekerjaan. Selama ini tunanetra di Indonesia banyak kehilangan hak-haknya. Hak yang hilang berupa hak menggunakan alat transportasi umum, hak memperoleh informasi, dan hak memperoleh pekerjaan (Medan Bisnis, 2011).

Para penyandang tunanetra menunjukkan penurunan kesejahteraan psikologis yang secara spesifik berkaitan dengan fungsi visualnya, misalnya dalam hal relasi sosialnya dan penerimaan dukungan sosial (Mclivane \& Reinhardt, 2001; Pinquart \& Pfeiffer, 2009). Selain itu, mereka cenderung mengalami stres lebih tinggi, tingkat kepuasan perkawinan yang lebih rendah, kesehatan mental dan kendali akan kesejahteraan psikologis yang menurun (Gardner \& Harmon, 2002). Bahkan apabila dibandingkan dengan populasi normal, para penyandang tunanetra di usia awal cenderung memiliki tingkat depresi yang lebih tinggi dan kesejahteraan yang lebih rendah. Diungkapkan pada studi yang sama, pada populasi tunanetra di Eropa, terganggunya fungsi penglihatan membawa dampak negatif terbesar dalam menurunkan kesejahteraan individu (Carney, 2004; Linely \& Joseph, 2005), sedangkan perbandingan antara populasi tunanetra bawaan (congenital blind) dan tunanetra setelah dewasa (late blind) dijelaskan bahwa kesejahteraan psikologis dan resiliensi late blind cenderung lebih rendah (Zeeshan \& Aslam, 2013). Padahal, Mills (2010) menjelaskan bahwa kesejahteraan psikologis merupakan indikator keseimbangan antara dampak negatif dan positif dari suatu kondisi yang dialami individu. Selain itu, kesejahteraan psikologis penting karena memiliki kesejahteraan psikologis yang tinggi akan mendukung kesehatan yang lebih baik, memperpanjang umur, meningkatkan usia harapan hidup, dan menggambarkan kualitas hidup dan fungsi individu (Diener dkk, 2009).

Ryff (dalam Papalia \& Feldman, 2002) menyebutkan ada enam dimensi kesejahteraan, yaitu penerimaan diri (self acceptance), hubungan positif dengan 
orang lain (positive relationship with others), kemandirian (autonomy), penguasaan lingkungan (environmental mastery), tujuan hidup (purpose in life), dan pertumbuhan personal (personal growth). Konstruk psychological well-being disusun berdasarkan teori perkembangan sepanjang hidup, yang berarti bahwa kondisi kesejahteraan psikologis individu bersifat dinamis (Ryff dalam Diener dkk, 2009). Pengalaman dalam kehidupan yang beragam dan unik akan memberikan pengaruh terhadap kondisi kesejahteraan psikologis secara terus-menerus. Kondisi tersebut menunjukkan bahwa pengalamanpengalaman dalam kehidupan pasca menjadi tunanetra juga akan berpengaruh pada kondisi kesejahteraan psikologis. Penelitian Halim dan Wirawan (2009) mengungkapkan hasil bahwa individu yang menderita penyakit kronis dan menjalani operasi serta pengobatan hingga kehilangan salah satu fungsi tubuh di usia dewasa akan memiliki peningkatan dalam pemahaman kesejahteraan psikologis. Keterbatasan fisik yang dimiliki individu akan meningkatkan kondisi kesejahteraan psikologis karena perubahan fungsi fisik berbanding lurus dengan peningkatan keyakinan terhadap Tuhan. Perubahan kondisi fisik mengubah pola pikir individu yang umumnya menjadi lebih positif dan memahami kondisi fisik yang sekarang, sehingga tingkat kesejahteraan psikologis individu menjadi tinggi dan meningkat. Selain itu, Zhong dkk (2013) mengungkapkan bahwa penyandang tunanetra dewasa yang berusaha mencari tujuan dan makna hidupnya, serta lebih memiliki keyakinan dan partisipasi religius cenderung lebih sejahtera dan mampu mengatasi depresinya.

Berdasarkan uraian di atas, tampak terdapat fakta yang menarik mengenai kesejahteraan psikologis penyandang tunanetra di usia dewasa awal (late blind). Berbagai studi terdahulu menunjukkan penurunan kesejah- teraan psikologis pada populasi late blind dan kondisi mereka merupakan kondisi kesejahteraan psikologis terendah apabila dibandingkan dengan populasi congenital blind dan populasi normal. Namun, hal tersebut tampaknya dapat diperbaiki dan berubah seiring dengan perubahan pandangan mereka terhadap hidup dan religiusitasnya. Berpijak dari hal tersebut maka penelitian ini berupaya untuk mengeksplorasi lebih dalam mengenai kesejah-teraan psikologis (psychological well-being) pada individu yang menjadi tunanetra di usia dewasa awal, dan secara khusus berupaya memahami perubahan dan anteseden dari kesejahteraan psikologis mereka.

\section{METODE}

Metode yang digunakan dalam penelitian ini adalah metode kualitatif fenomenologi, yang mampu mengeksplorasi pengalaman subjek sejak mereka masih menjadi individu awas hingga menjadi tunanetra, serta memahami perubahan pada kesejahteraan psikologis mereka karena pengalaman hidupnya juga bertambah dan mengalami hal berbeda setelah mengalami kebutaan. Fenomenologi berusaha menemukan makna psikologis yang terkandung dalam fenomena melalui penyelidikan dan analisis contoh-contoh hidup. Selaras dengan hal tersebut, analisis data yang digunakan adalah Interpretative Phenomenological Analysis (IPA) yang dikembangkan oleh Smith (Smith, Flowers \& Larkin, 2009). Tujuan dari IPA untuk melakukan investigasi mengenai bagaimana seseorang memahami pengalamannya, yang berarti subjek secara aktif terikat dengan interpretasi terhadap peristiwa, objek, orang lain di kehidupannya. Untuk memahami hal tersebut IPA menggunakan prinsip-prinsip fenomenologi, herme-neutik, dan idiografi (Taylor dalam Pietkiewicz \& Smith, 2012). 
Subjek pada penelitian ini dipilih melalui teknik purposive. Subjek terdiri dari dua orang individu, dengan karakteristik: (1) mengalami kehilangan penglihatan di kedua matanya (totally blind), (2) mengalami kebutaan tersebut terjadi di usia dewasa awal (late blind), yaitu antara usia 20 sampai 40 tahun, (3) menempuh pendidikan minimal sekolah menengah atas (SMA/sederajat) dan (4) berjenis kelamin laki-laki. Hal ini dipilih sebagai upaya dalam memenuhi tujuan dari IPA yang mengedepankan kedalaman data daripada keluasannya (Smith, 2004), selain untuk memenuhi syarat homogenitas sampel, dimana dalam IPA kesamaan dan perbedaan psikologis dianalisa dalam kelompok (within group) sebagai kesamaan dalam mencapai variabel-variabel penting (Pietkiewicz \& Smith, 2012).

Peneliti menggunakan teknik pengambilan data berupa metode wawancara mendalam semi terstruktur yang merupakan salah satu syarat dalam IPA (Pietkiewicz \& Smith, 2012), observasi non-partisipan pada aktivitas subjek, dan wawancara pada triangulan. Pertanyaan penelitian yang diajukan adalah "Bagaimanakah pengalaman subjek hingga menjadi tunanetra?"; “Apa sajakah problem yang dihadapi setelah menjadi tunanetra?"; dan "Bagaimanakah pemahaman subjek mengenai kesejahteraan psikologisnya? Adakah perubahan sebelum dan sesudah menjadi tunanetra? Apa sajakah yang mempengaruhinya?"

Setelah melakukan pengambilan data, dilakukan langkah-langkah berikut ini sesuai dengan Smith, Flowers, dan Larkin (2009). Pertama-tama setelah melakukan wawancara, peneliti akan mentranskripsikan hasil wawancara, kedua mendeskripsikan pengalaman di lapangan untuk memudahkan peneliti dalam memahami pernyataan-pernyataan subjek.
Selanjutnya, langkah ketiga setelah hasil wawancara diubah dalam bentuk transkrip, kemudian dibaca dengan teliti dan berulang-ulang, transkrip diatur berdasarkan alur atau topik dari subjek dan disalin pada sebuah kolom di halaman terpisah. Di samping kolom yang berisi transkrip lengkap tersebut kemudian ditambahkan kolom untuk catatan peneliti yang berisi kesimpulan, petikan kata-kata subjek yang dinilai penting, kesimpulan, asosiasi yang muncul atau interpretasi awal dari peneliti. Di samping kolom catatan peneliti ditambahkan satu kolom lagi untuk judul tema yang merupakan istilah dalam psikologi atau gambaran kondisi subjek berdasarkan catatan peneliti yang sudah ada. Langkah keempat peneliti menuliskan tema-tema yang muncul dari transkrip dalam lembar terpisah dan mencari hubungan diantara tema-tema tersebut. Langkah ini disebut sebagai clustering theme. Beberapa tema dapat dikelompokkan menjadi satu dan menjadi konsep utama yang dapat melengkapi tema ini. Tema ini disebut sebagai tema utama. Tema utama menggambarkan perhatian terbesar subjek terhadap sebuah topik. Langkah kelima, adalah membuat dan mengatur daftar tema yang saling berhubungan. Daftar tema ini dituliskan dalam tabel pengelompokkan tema. Dalam daftar ini, tema utama dan sub tema yang sudah disusun dalam clustering theme dituliskan dalam satu kolom. Di samping tema utama dan subtema kemudian ditambahkan dua kolom. Satu kolom berisi kata kunci yang merupakan ucapan subjek yang diambil dari transkrip yang menunjukkan tema yang berkaitan. Satu kolom lain digunakan untuk menuliskan keterangan letak kata kunci, yaitu halaman dan baris dari kata kunci dalam transkrip. Selanjutnya, langkah keenam adalah deskripsi tekstural, tema-tema yang telah ditemukan, nantinya akan dideskripsikan berdasarkan pada ucapan subjek yang 
asli/orisinil/harfiah/verbatim. Ucapan-ucapan subjek ini didapatkan dari proses penelusuran tema-tema. Langkah ketujuh, adalah deskripsi struktural dengan memasukan hasil interpretasi terhadap ucapan subjek yang verbatim. Deskripsi struktural dicantumkan setelah verbatim dari subjek. Kedelapan, menyusun makna atau esensi dari pengalaman subjek, dengan menyusun keseluruhan tema-tema, deskripsi tekstural, serta deskripsi struktural disatukan untuk dicari makna universal atau esensi dari pengalaman subjek penelitian. Berdasar tabel pengelompokkan tema masing-masing subjek, peneliti kemudian membuat dinamika psikologis masing-masing subjek, dalam bentuk: (1) tema-tema emergen; (2) tema-tema subordinat; (3) tema-tema (superordinat) induk. kan observasi kegiatan kedua subjek dilakukan sebanyak enam kali, pada aktivitas di "Komunitas Sahabat Mata" (KSM), di rumah dan tempat kerja kedua subjek. Sedangkan wawancara pada triangulan subjek dilakukan pada kakak, teman, dan pasangan subjek. Data penelitian ini merupakan data sekunder dari penelitian terdahulu yang berlangsung antara tahun 2011-2012 (Harimukthi, 2012).

Analisis yang dilakukan mengungkapkan adanya tema-tema emergen dari kedua subjek yang kemudian dideskripsikan secara tekstural dan struktural disarikan dalam tema-tema subordinat dan tematema superordinat (induk) dengan teknik clustering, yang berlandaskan pemahaman idiografik (Merrit \& Miller, 2014; Smith, Flowers, \& Larkin, 2009), dengan hasil seperti dalam Tabel 2.

Tabel 1

Karakteristik subjek penelitian

\begin{tabular}{lll}
\hline Karakteristik & Subjek \#1 & Subjek \#2 \\
\hline Inisial & BS & JT \\
Jenis kelamin & Laki-laki & Laki-laki \\
Agama & Islam & Islam \\
Usia & 39 tahun & 26 tahun \\
Pendidikan & SMA & STM Otomotif \\
Kepastian diagnose & Tahun 2004 (31 tahun) & Tahun 2008 (22 tahun) \\
Status & Menikah & Menikah \\
Pekerjaan saat ini & Reparasi dan jual beli komputer & Tukang pijat dan penjual pulsa \\
\hline
\end{tabular}

\section{HASIL DAN PEMBAHASAN}

Pada Tabel 1, dapat diamati karakteristik subjek penelitian berdasarkan usia, jenis kelamin, agama, tingkat pendidikan, kapan didiagnosa kebutaan, status perkawinan, dan jenis pekerjaannya. Peneliti melakukan wawancara mendalam terhadap kedua subjek (BS dan JT) selama masing-masing lima kali, dengan rentang waktu wawancara 3 Juni 2011-17 April 2012. Sedang-
Dari tiga tema superordinat (tema induk) yang diungkap, yaitu (1) Menjadi tunanetra, dengan enam tema subordinat, (2) Dukungan sosial, dengan empat tema subordinat, dan (3) Kesejahteraan psikologis, dengan sepuluh tema subordinat, menarik untuk dipahami lebih jauh karena adanya tahapan dalam mencapai kesejahteraan psikologis yang dirasakan subjek semakin positif bahkan apabila dibandingkan keduanya dari kehidupan 
Tabel 2

Representasi tema-tema subordinat dan tema-tema superordinat (induk)

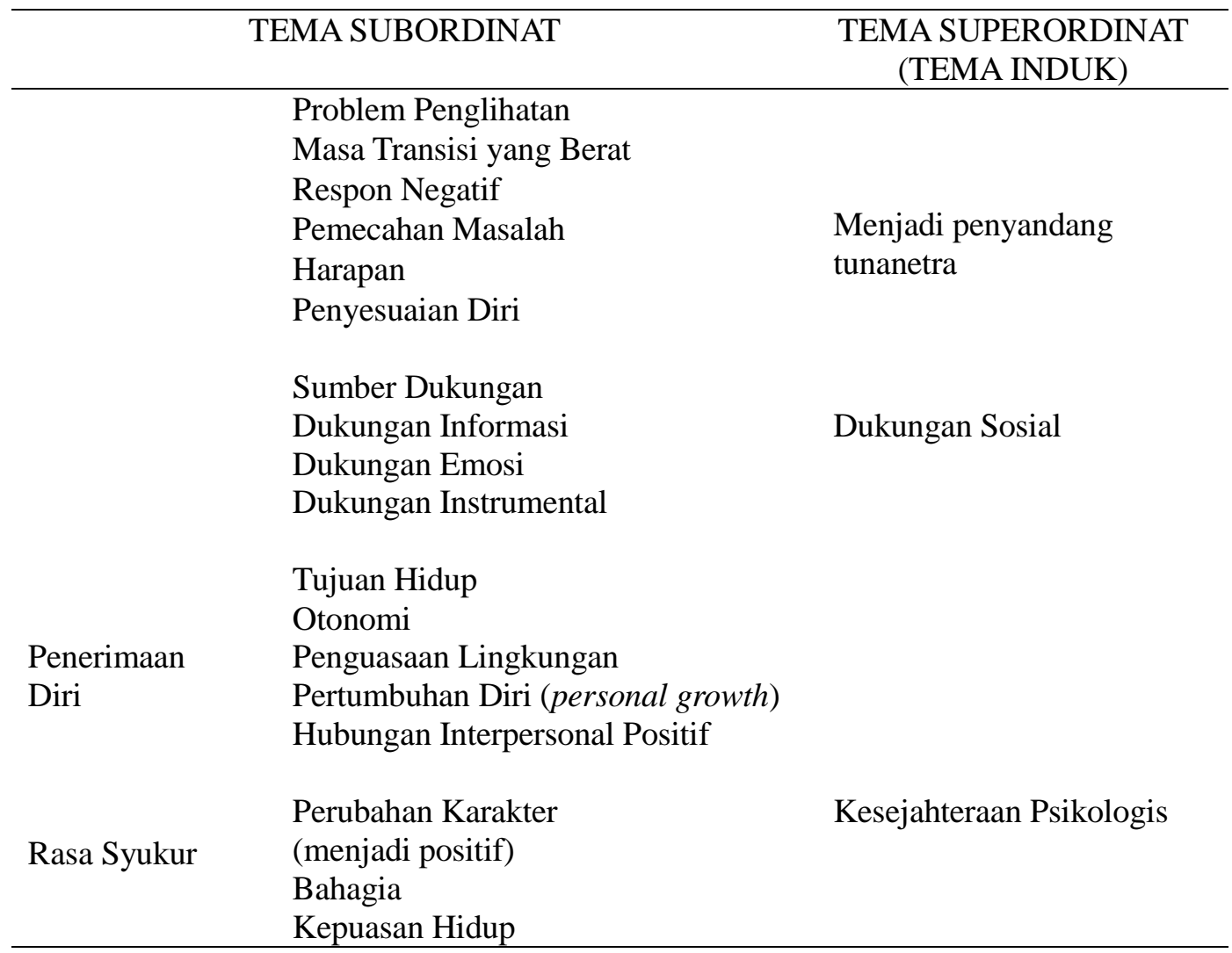

sebelum menjadi tunanetra dan pola-pola yang sama diantara keduanya.

Dalam menjawab pertanyaan penelitian mengenai "Bagaimanakah pengalaman subjek hingga menjadi tunanetra?", tampaknya keduanya mengalami pengalaman memburuknya fungsi penglihatan sejak usia muda, seperti berikut ini:

"tahun 99, saya didiagnosis kena glaucoma...” (subjek BS-A2.1.14).

"awalnya pas mau mudik naik motor ... tahun 2007... sampe situ sudah byar pet, kadang lihat kadang nggak... kata dokter kena saraf mata, saraf rusak kena virus efek dari minuman keras" (subjek JT-B1.2.36; B1.3.2).

Dan sejak saat itulah proses menjadi penyandang tunanetra diawali dengan tahapan terjadinya problem penglihatan, masa transisi yang berat karena harus melakukan penyesuaian dari perasaan tidak berdaya, menurunnya kemampuan berkomunikasi, dan penurunan kemampuan mobilisasi. Tahapan ini berlanjut dengan munculnya respon-respon negatif baik berupa emosi negatif seperti sedih, marah, ketakutan, kecewa, menarik diri, curiga dan stres pada kedua subjek, serta respon pihak lain seperti keluarga dan teman-teman yang shock. Hal tersebut tercermin dalam ungkapan berikut:

“... ya, kemudian rasa takut, rasa curiga, ... sebenarnya saya nangis juga, sedih" (subjek BS-A1.3.6; A2.2.41).

“...dulu sangat gelo, nyesel, kok begini...tambah tertekan dengan penyakit mata, mau ini gak bisa... merasa takut kalau sendirian...perasaan kecewa, 
pengennya marah..." (subjek JT-B1.3.10; B1.3.20).

Temuan tersebut mendukung penjelasan Scherer (dalam Lilienfeld dkk, 2010) bahwa kehilangan penglihatan di usia dewasa awal menjadi salah satu bentuk cacat fisik yang menghambat tugas perkembangan individu. Kondisi tunanetra yang dialami individu akan me nimbulkan respon emosional. Respon emosional yang muncul ditentukan oleh bagaimana subjek menginterpretasikan situasi yang terjadi. Emosi merupakan suatu kondisi fisik, mental, dan tingkah laku yang diasosiasikan dengan evaluasi terhadap pengalaman individu. Kedua subjek mempersepsikan bahwa tunanetra adalah sesuatu yang menghambat proses kehidupan selanjutnya, sehingga muncul respon emosi kemarahan, kecemasan, ketakutan, kekecewaan, kehilangan percaya diri, perasaan tidak berdaya, dan tergantung pada orang lain.

Kedua subjek menyatakan bahwa keduanya menjadi mudah marah dan cemas setelah tunanetra. Kemarahan yang muncul disebabkan karena ketidakmampuan dalam melakukan sesuatu sehingga diluapkan dengan emosi marah. Subjek BS cenderung melampiaskan kemarahan kepada pasangannya sedangkan subjek JT cenderung melampiaskan kemarahan kepada kakaknya. Kecemasan merupakan jenis emosi yang kompleks karena kecemasan merupakan emosi yang tidak menyenangkan namun diperlukan bagi individu sebagai sistem alarm (Gorman dalam Dewi, 2010). Subjek JT mengalami kecemasan karena kondisinya saat menjadi tunanetra belum memiliki pasangan. Kecemasan subjek JT merupakan bentuk kecemasan yang berkaitan dengan pemenuhan salah satu tugas perkembangan pada masa dewasa awal, yaitu memiliki pasangan dan pekerjaan.
Sedangkan pertanyaan "Apa sajakah problem yang dihadapi setelah menjadi tunanetra?", penjelasannya terungkap dalam tema subordinat masa transisi yang berat. Tema ini dimiliki kedua subjek dengan penjelasan dalam tema-tema emergen harus melakukan penyesuaian dari perasaan tidak berdaya, menurunnya kemampuan berkomunikasi, dan penurunan kemampuan mobilisasi. Selain itu, subjek JT juga menyampaikan pengalamannya merasa harus bergantung pada orang lain, kebutaan mengurangi otonominya sebagai individu, dan merasakan penolakan lingkungan sekitar.

"pekerjaan gak bisa...mobilitas kurang...hubungan sosial kacau...ya, rasa takut saja (tertawa), rasa gak pede aja gitu” (subjek BS-A2.3.42; A2.4.3-8).

“...dulu bisa mandiri bekerja, sampe sekarang ....masih mengandalkan orang lain. Keterbatasan saya untuk mobilitas. (subjek JT-B1.4.2; B2.6.10).

Hasil ini mendukung hasil studi mengenai dampak kebutaan pada subjek remaja dan dewasa awal (Gardner \& Harmon, 2002; Kef \& Dekovic, 2004) yang mengungkapkan bahwa penyandang tuna netra di usia remaja dan dewasa awal cenderung mengalami permasalahan dengan dunia eksternalnya dan hal ini mempengaruhi rasa bahagia dan penyesuaian sosialnya.

Untuk pertanyaan penelitian "Bagaimanakah pemahaman subjek mengenai kesejahteraan psikologisnya? Adakah perubahan sebelum dan sesudah menjadi tunanetra? Apa sajakah yang mempengaruhinya?", terungkap dari kedua subjek dalam tema-tema superordinat menjadi penyandang tunanetra, dukungan sosial, dan kesejahteraan psikologis. Kedua subjek menyatakan adanya perbedaan pemahaman akan makna kesejahteraan 
psikologis bagi mereka dulu sebelum mengalami kebutaan dengan kini setelah mengalami kebutaan. Keduanya menyatakan sejahtera diukur dengan kemandirian (otonomi) baik dalam aktivitas (subjek BS) dan finansial, kondisi semua baik, ada orang-orang yang membantu dan pikiran rileks (subjek JT). Kini keduanya lebih memahami rasa sejahtera terkait dengan bahagia di hati dan membahagiakan keluarga. Selain itu, kedua subjek juga mengakui adanya kemerosotan kesejahteraan setelah mengalami kebutaan, namun seiring dengan pemecahan masalah, penyesuaian diri, dan penerimaan diri mereka terhadap kondisi kebutaannya, maka kesejahteraan dapat dirasakan kembali. Mereka menyatakan dukungan sosial dari keluarga, pasangan, dan teman, serta pemecahan masalah dengan pendekatan pada agama, rasa syukur akan hidup yang dimiliki membantu mereka dalam mencapai kesejahteraan psikologis dan berujung pada rasa bahagia.

Proses tersebut, diawali dari munculnya berbagai respon emosi dan hambatan yang membuat kedua subjek berusaha mencari solusi agar dapat menyesuaikan diri dengan kondisi baru. Kedua subjek menjalankan pengobatan untuk mengembalikan fungsi peng-lihatannya. Subjek BS menjalani operasi mata sebanyak dua kali sedangkan subjek JT menjalani pengobatan secara alternatif. Kedua usaha pengobatan yang dilakukan subjek tidak berhasil. Kedua subjek melakukan regulasi diri sebagai proses pengaturan diri yang mencakup mencapai tujuan, memotivasi serta membimbing perilaku. Subjek BS meregulasi emosinya dengan tidak meluapkan emosi kemarahan akibat kondisi tunanetra. Sementara subjek JT meregulasi perilakunya degan menahan diri untuk tidak meluapkan emosi negatif dan meminimalisir perilaku yang dianggap negatif dan dapat berdampak buruk. Kedua subjek juga melakukan pengendalian diri untuk mengatasi respon emosi yang muncul. Subjek BS lebih memilih untuk mendengarkan siaran radio, tidur, bermain dengan anak, dan menyendiri di kamar untuk mengatasi berbagai respon emosi yang muncul. Sementara subjek JT lebih senang merenung dan berdiam diri di kamar. Subjek JT melakukan berusaha meningkatkan keimanan dengan melaku-kan ibadah berupa sholat wajib, sholat sunnah duha dan tahajud, serta mendengarkan murotal dan hadist-hadist melalui audiobooks untuk tunanetra. Temuan mengenai pemecahan masalah yang bersifat religius pada kedua subjek di atas, sejalan dengan studi yang dilakukan Pheng dan Zhang (2010) yang mengungkapkan bahwa penyandang cacat tubuh yang memiliki kepercayaan religius dapat memiliki faktor melawan depresi dan kondisi kesehatan mental yang lebih baik.

Pada proses penyesuaian diri kedua subjek dengan kondisi baru sebagai tunanetra, berbagai cara dilakukan. Subjek BS akhirnya membentuk sebuah komunitas tunanetra yang memiliki tujuan untuk melakukan pendampingan terhadap individu tunanetra dan keluarganya. Komunitas ini juga mengajarkan kepada tunanetra keterampilan membaca Al-Qur'an braille, siaran radio, memijat, serta komputer bicara. Subjek BS juga mempelajari kembali tentang komputer dan cara memperbaikinya, sampai akhirnya subjek berhasil mendirikan sebuah usaha jasa reparasi dan jual komputer dimana penghasilannya digunakan untuk biaya operasional komunitas. Sedangkan subjek JT mengalami perubahan setelah bergabung dengan komunitas yang dibentuk oleh subjek BS. Subjek JT belajar memijat dan mampu hidup secara mandiri dari keahliannya memijat. Komunitas Sahabat Mata (KSM) memberikan banyak motivasi, inspirasi, 
dan semangat kepada subjek JT. Subjek merasa memiliki kemampuan dalam melakukan banyak hal setelah melihat kondisi tunanetra di dalam komunitas dapat hidup mandiri. BS dan JT aktif dalam komunitas tersebut bukanlah hal yang tiba-tiba. Menurut Zhong, dkk (2013) individu penyandang cacat yang mengembangkan kehidupannya lebih religius dari sebelumnya dapat memiliki emosi yang stabil dan memperoleh kesempatan untuk mulai memikirkan makna hidupnya, serta mengisi hidup yang lebih bermanfaat bagi orang lain. Sehingga dapat disimpulkan bahwa mendalami kehidupan yang religius merupakan salah satu langkah menuju terbukanya pemikiran akan makna hidup dan kebermanfaatan hidup bagi orang lain.

Proses penyesuaian diri tersebut tidak terlepas dari berbagai bentuk dukungan sosial yang diberikan kepada kedua subjek. Cob (dalam Sarafino, 2005) mengemukakan bahwa dukungan sosial mengacu pada persepsi kenyamanan, kepedulian, penghargaan atau bantuan yang diterima dari orang lain atau kelompok dalam masyarakat. Subjek BS mendapatkan dukungan penuh dari pasangan, keluarga, anak- anak, dan teman-temannya. Marital support dari pasangan membantu subjek dalam menyesuaikan dan menerima kondisi diri. Material support dan informational support yang diberikan keluarga dalam bentuk informasi dan biaya pengobatan membantu subjek dalam menyesuaikan diri. Subjek BS memiliki keterampilan sosial yang tinggi sehingga membuatnya lebih mudah dalam menyesuaikan diri dengan lingkungan. Keterampilan sosial yang tinggi ditandai oleh jaringan sosial yang luas, subjek BS sebelum menjadi tunanetra adalah seorang aktivis sehingga setelah menjadi tunanetra banyak teman-teman yang datang menengok dan memberikan dukungan serta kesempatan bagi subjek untuk berkembang dan beraktivitas.

Subjek JT mendapat dukungan sosial dari keluarga dan teman-teman. Saat awal menjadi tunanetra subjek belum menikah, sehingga kakak kandung dan kakak ipar yang sangat memiliki peran dalam memberi dukungan. Kedua kakaknya mengusahakan pengobatan, memberi perhatian, dan menerima kondisi subjek sebagai tunanetra. Sementara temanteman subjek setiap malam datang menjenguk untuk menghibur subjek. Lingkungan tempat tinggal memberi dukungan dengan tidak menjauhi subjek dan tetap diikutsertakan dalam kegiatan di lingkungan tempat tinggal. Subjek JT mendapat dukungan sosial dari pasangan setelah akhirnya subjek menikah dengan seorang relawan di komunitas Sahabat Mata. Dukungan sosial yang diterima membantu subjek dalam penyesuaian diri.

Respon emosi yang muncul akibat tunanetra juga mengiringi proses penyesuaian diri yang dilakukan individu mampu merubah karakter kedua subjek. Keduanya cenderung memiliki perbedaan karakter dari sebelum dan setelah tunanetra. Subjek BS cenderung menjadi individu yang lebih sabar serta mau mendengarkan pendapat dan masukan dari orang lain. Subjek BS juga cenderung membutuhkan orang lain untuk membantu membuat sebuah keputusan maupun membantu dalam mobilitas. Subjek JT cenderung menjadi individu yang lebih sabar dan tenang dalam menghadapi setiap permasalahan. Subjek JT juga cenderung menjadi berani untuk berbicara setelah tunanetra. Perubahan lain yang terjadi pada subjek JT adalah intensitas beribadah. Subjek JT menjalankan kembali ibadahnya setelah menjadi tunanetra. Perubahan kedua subjek tidak terlepas dari kondisi kesejahteraan psikologisnya. 
Kesejahteraan psikologis adalah kondisi individu yang sehat secara psikologis, memiliki sikap positif terhadap dirinya dan orang lain. Individu mampu membuat keputusan sendiri, mengatur perilakunya sendiri, dan memilih atau membentuk lingkungan yang sesuai dengan kebutuhannya. Individu memiliki banyak tujuan yang membuat hidupnya bermakna, berjuang untuk menjelajahi, dan mengembangkan diri selengkap mungkin (Ryff, dalam Papalia \& Feldman, 2002). Subjek BS mendefinisikan kesejahteraan psikologis sebagai kondisi dimana seseorang dapat mengontrol diri karena sejahtera bukan hanya terlepas dari rasa takut, marah, rasa yang dianggap negatif. Kesejahteraan juga didefinisikan sebagai kondisi yang memiliki tingkatantingkatan, yaitu terpenuhinya kebutuhan materi, kemampuan menghargai antar individu, dan kemampuan mencapai kesejahteraan yang diimbangi dengan pencapaian kebahagiaan. Sedangkan subjek JT mendefinisikan kesejahteraan psikologis sebagai kondisi individu yang terpenuhi kebutuhan materi dan memiliki pemikiran positif. Subjek JT juga menjelaskan bahwa individu yang sejahtera lebih memikirkan kehidupan mendatang daripada memikirkan hal-hal di masa lalu karena individu cenderung bersikap positif.

Subjek BS menunjukan karakteristik penerimaan diri yang baik sementara subjek JT menunjukan karakteristik penerimaan diri yang kurang baik di awal. Kedua subjek dapat menerima dan mengakui kualitas dirinya baik yang positif maupun yang negatif. Kedua subjek telah memiliki sikap yang positif terhadap dirinya sendiri saat ini. Kedua hal tersebut merupakan indikator adanya penerimaan diri yang baik. Karakteristik penerimaan diri yang buruk di awal masa tunanetra ditunjukkan oleh kedua subjek adalah menutup diri untuk berinteraksi dengan orang lain selain dengan pasangan dan keluarga.

Dimensi kesejahteraan psikologis, hubungan positif juga terpengaruh oleh pengalaman sebagai tunanetra. Pada masa awal terjadinya tunanetra kedua subjek mengalami isolasi diri sehingga menutup diri untuk berinteraksi dengan orang lain. Subjek BS hanya mau berinteraksi dengan pasangan dan keluarga sementara subjek JT hanya mau berinteraksi dengan keluarga. Kedua subjek sempat sempat mengalami peer rejection setelah mengalami ketunanetraan. Keterasingan dan ketidakmampuan membangun hubungan yang hangat dan saling percaya merupakan karakteristik dari hubungan positif yang buruk. Sekarang, hubungan positif subjek JT telah membaik. Subjek JT sudah dapat memiliki hubungan yang hangat dan terbuka dengan orang lain setelah mendapatkan dukungan sosial, terutama dari keluarga dan peer. Subjek BS dapat kembali memiliki hubungan yang hangat dan terbuka dengan orang lain setelah mendapatkan dukungan sosial, terutama dari pasangan dan keluarga. Subjek BS mampu menampilkan empati dan kepedulian terhadap orang lain. Bentuk empati dan kepedulian yang dilakukan oleh subjek BS adalah dengan membentuk sebuah komunitas untuk tunanetra (Ryff dalam Papalia \& Feldman, 2002).

Otonomi yang baik dicirikan dengan karakteristik individu mandiri, mampu mengevaluasi diri dengan standar pribadi, serta dapat menolak tekanan sosial untuk mengikuti cara berpikir atau perilaku tertentu (Ryff dalam Bornstein, dkk, 2008). Kedua subjek menunjukkan otonomi yang baik ditandai dengan pencapaian mereka. Subjek BS kehilangan pekerjaan sebagai penjual buku namun berkat kegigihannya mempelajari komputer akhirnya subjek 
mampu membuka sebuah usaha reparasi dan jual beli komputer. Subjek BS juga mampu bepergian keluar kota sendirian tanpa pendamping. Subjek BS sudah mau menerima pendapat orang lain walaupun berbeda dengan pendapatnya. Sementara subjek JT membangun otonomi sejak bergabung dalam komu-nitas tunanetra. Subjek JT belajar memijat dan bepergian sendirian tanpa pendamping. Subjek JT cenderung mengikuti pendapat dan perilaku orang lain dalam proses pencapaian otonomi. Saat ini subjek JT sudah mampu mengontrak rumah, tinggal bersama keluarga, serta membuka usaha pijat di rumah.

Penguasaan lingkungan yang baik ditandai oleh perasaan kompeten menguasai lingkungan serta dapat memilih atau menciptakan lingkungan yang cocok dengan dirinya. Penguasaan lingkungan yang buruk ditandai oleh kesulitan mengelola aktivitas sehari-hari, ketidakmampuan memilih atau menciptakan lingkungan yang sesuai, serta kurangnya kesadaran akan peluang yang ditawarkan. Subjek BS memiliki kemampuan yang baik dalam penguasaan lingkungan dan ditandai dengan kemampuannya mengatur kegiatan sehari-hari sebagai seorang ketua komunitas dan wiraswasta. Subjek JT memiliki kecenderungan mengikuti aktivitas yang dilakukan oleh temanteman di dalam komunitas. Subjek JT menemui kesulitan dalam berinteraksi dengan lingkungan di luar kelurga dan komunitas. pengalaman sebagai individu tunanetra mempengaruhi dimensi penguasaan lingkungan pada kedua subjek.

Kondisi tunanetra mempengaruhi dimensi kesejahteraan psikologis yang selanjutnya, yaitu tujuan hidup. Kedua subjek saat ini memiliki keberarahan, mampu melihat tujuan dan makna dari pengalaman, serta memiliki pegangan dan keyakinan dalam hidup setelah menjadi tunanetra. Subjek JT sempat merasa hidupnya kurang bermakna karena diisi dengan hura-hura, obat-obatan, serta minum minuman keras. Saat ini subjek JT sudah mampu memaknai kehidupannya dengan tujuan hidup ingin membahagiakan pasangan dan keluarga. Subjek JT mampu menemukan makna hidup setelah mampu menerima diri dan memilki pasangan. Subjek BS merasakan kehidupannya jauh lebih bermakna setelah menjadi tunanetra. Subjek BS merasakan bahwa dirinya semakin memiliki manfaat untuk sekitarnya. Kedua subjek memiliki tujuan hidup tertinggi yaitu setelah meninggal dapat masuk surga dan bertemu dengan Tuhan. Kedua subjek mengembangkan target yang ingin dicapai serta strategi mencapai target tersebut. Kondisi tersebut menunjukkan perbaikan dalam tujuan hidup subjek (Ryff dalam Papalia \& Feldman, 2002).

Dimensi terakhir dari kesejahteraan psikologis, yaitu pertumbuhan personal juga dipengaruhi oleh pengalaman menjadi seorang tunanetra. Kedua subjek merasakan perkembangan dalam dirinya. Subjek BS merasakan perkembangan dalam relasi sosial dan kedekatan keluarga serta dapat meningkatkan perilaku empati dan kepedulian melalui komunitas yang dibentuk. Subjek BS juga telah merasa lebih dapat mengontrol emosi, lebih dewasa, lebih bijak dalam mempersepsikan peristiwa yang terjadi dalam dirinya. Subjek JT telah merasakan perkembangan setelah menikah dan memiliki anak. Subjek JT menjadi lebih mampu mengembangkan sikap dan perilaku yang baru serta terbuka pada pengalaman baru. Perasaan akan perkembangan, kemampuan mengembangkan perilaku baru, kemampuan melihat perubahan dalam diri serta 
keterbukaan pada pengalaman baru merupakan karakteristik dari pertumbuhan personal yang positif (Ryff dalam Papalia, 2002).

Kondisi awal saat kedua subjek sebagai tunanetra, memunculkan karakteristik pertumbuhan personal yang negatif namun seiring berjalannya waktu pertumbuhan personal yang positif. Subjek BS melakukan perubahan dalam diri yang ditandai dengan upaya untuk mempelajari kebutuhan-kebutuhan tunanetra dan membentuk komunitas. Sementara subjek JT pada awal masa tunanetra merasa diriny tidak dapat berkembang dan tidak dapat melihat arah dalam kehidupannya namun setelah menikah subjek menemukan arah hidup. Uraian tersebut menjelaskan bahwa pengalaman dan perubahan diri menjadi seorang tunanetra mempengaruhi kesejahteraan psikologis. Kondisi tunanetra dimaknai sebagai pengalaman yang menimbulkan berbagai perasaan negatif sehingga memberikan pengaruh negatif juga bagi kesejahteraan psikologis.

Kondisi kesejahteraan psikologis subjek terutama pada dimensi penerimaan diri, hubungan positif dengan orang lain, penguasaan lingkungan, otonomi, serta pertumbuhan personal sempat memburuk. Perubahan kondisi kesejahteraan subjek dipengaruhi oleh berbagai macam faktor, antara lain adanya dukungan sosial, karakteristik kepribadian, perubahan tingkat religiusitas, serta pengalaman hidup dan interpretasinya. Karakteristik kepribadian dicirikan dengan pertumbuhan pemahaman diri dan pertumbuhan karakter diri yang selalu berkembang selama rentang kehidupan. Karakteristik kepribadian ditandai dengan tipe kepribadian yang dimiliki individu. Saat ini subjek telah menunjukkan indikator yang positif dari dimensidimensi penerimaan diri, hubungan positif dengan orang lain, tujuan hidup, penguasaan lingkungan, tujuan hidup, dan pertumbuhan personal pada kesejahteraan psikologis individu.

\section{KESIMPULAN}

Berdasarkan temuan penelitian, dapat disimpulkan bahwa kesejahteraan psikologis semua subjek mengalami perubahan akibat kebutaan yang dialaminya ketika usia dewasa awal. Di awal munculnya gejala, menurunnya kemampuan berkomunikasi, penurunan kemampuan mobilisasi, dan respon emosi negatif diungkap semua subjek sebagai anteseden menurunnya kesejahteraan psikologis mereka. Sedangkan peningkatan kesejahteraan psikologis disebabkan oleh adanya dukungan sosial berupa dukung-an emosi, informasi, dan instrumental yang bersumber dari keluarga, pasangan, teman, dan kelompok. Meskipun kedua-nya memiliki strategi coping yang berbeda, namun peningkatan kesejahteraan psikologis dapat dirasa-kan keduanya, setelah penerimaan diri berhasil diraihnya. Yang menarik adalah terungkapnya dimensi penerimaan diri sebagai dimensi awal yang membantu subjek dalam mencapai dimensi-dimensi kesejahteraan psikologis yang lain, yaitu tujuan hidup, kemandirian, penguasaan lingkungan, pertumbuhan personal, dan hubungan positif dengan orang lain. Keenamnya dimensi ini muncul secara tidak bersamaan, namun sesuai dengan gambaran dimensi yang diungkapkan oleh Ryff dan Keyes (Papalia \& Feldman, 2002). Selain itu, munculnya dimensi religiusitas dalam pencapaian kesejahteraan psikologis dan kebahagiaan kedua subjek menunjukkan adanya keterkaitan diantara keduanya. 


\section{DAFTAR PUSTAKA}

Anna, K. L. (2011). Katarak penyebab utama kebutaan. Diambil dari Kompas Online http://health.kompas. com/read/2011/06/23/06230534/Katara k.Penyebab.Ut ama.Kebutaan

Medan Bisnis. (2011). Duh, tunanetra ditolak jadi nasabah. Diambil dari Medan Bisnis. Online http://www.medanbisnisdaily.com/news /read/2011/12/02/69596/duh_tun a_netra_ditolak_jadi_nasabah_bank/\#.T w4GNHqmPMw

Bornstein, M., Davidson, L., Keyes, C., \& Moore, K. (2008). Well-being positive development across the life course. New Jersey: Lawrence Erlbaum Associates, Inc.

Charney, D. S. (2004). Psychological mechanism of resilience and vulnerability: Implication for successful adaptation to extreme stress. American Journal of Psychology, 161(2), 195-216.

Crews, J. \& Campbell, V. A. (2004). Vision impairment and hearing loss among community-dwelling older americans: Implications for health and functioning. American Journal of Public Health, 94, 823-829.

Delphie, B. (2006). Pembelajaran anak berkebutuhan khusus. Bandung: Refika Aditama.

Dewi, K. S. (2010). Kesehatan mental. Semarang: Undip Press.

Diener, E., Wirtz, D., Biswas-Diener, R., Tov, W., Kim-Prieto, Chu, Choi, Dong-won, \& Oishi, S. (2009). New measures of well-being. E. Diener (ed.), Assessing well-being: The collected works of Ed Diener, Social
Indicators Research Series 39, doi: 10.1007/978-90-481-2354-4 12.

Gardner, J., \& Harmon, T. (2002). Exploring resilience from parent's perspective: A qualitative study of six resilient mothers of children with intellectual disability. Australian Social Work, 55(1), 60-68.

Halim, W. \& Wirawan, H. (2009). Quality of Life Janda Pasca Kemoterapi dan Radioterapi. Skripsi (tidak diterbitkan). Universitas Tarumanegara.

Harimukthi, M. T. (2012). Psychological well-being pada individu yang kehilangan penglihatan di usia dewasa awal. Skripsi (tidak diterbitkan). Universitas Diponegoro.

Kef, S. \& Dekovic, M. (2004). The role of parental and peer support in adolescents well-being: A comparison of adolescents with and without a visual impairment. Journal of Adolescence, 27(4), 453-466.

Lilienfeld, S., Lynn, S., Namy, L., \& Woolf, N. (2010). Psychology : A framework for everyday thinking. Boston: Pearson Education, Inc.

Linely, P. A. \& Joseph, S. (2005). The human capacity for growth through adversity. The American Psychologist, 60(3), 262-264.

Mclivane, J. M. \& Reinhardt, J. P. (2001). Interactive effect of support from family and friends in visually impaired elders. The Journals of Gerontology, B series, Psychological Sciences and Social Sciences, 56(6), 374-382.

Merrit, L. H. \& Miller, P. K. (2014). Anxiety, physical activity, and public 
performance: An interpretative phenomenological analysis of amateur gymnasts' competition experiences. Cumbria Partnership Journal of Research Practice and Learning, 4(1), 12-17.

Mills. (2010). Psychological well-being in long term care. Diambil dari http://gerospychology.wordpress.com/2 010/01/psychological-well-being-inlong-term-care/

Papalia, D. E, Old, S. W., \& Feldman, R. D. (2002). Human development. New York: McGraw-Hills.

Pheng \& Zhang (2010). Review on the relationship between religion and mental health. Medicine and Philosophy (Humanistic and Social Medicine Edition), 31(10), 53-55.

Pietkiewicz, I. \& Smith, J. A. (2012). A practical guide to using interpretative phenomenological analysis in qualitative research psychology (in polish language). Psychological Journal (Czasopismo Psychologiczne), 18(2), 361-369.

Pinquart, M. \& Pfeiffer, J. P. (2009). Psychological well-being in visually impaired and impaired individuals. British Journal of Visual Impairment, 29(1), 27-45.
Sarafino, E. P. (2005). Health psychology biopsychosocial interactions. Canada: John Willey \& Sons, Inc.

Sardegna, J., Shelly, S., Rutzen, A. R., \& Steidl, S. M. (2002). The encyclopedia of blindness and vision impairement. New York: Facts On File, Inc.

Smith, J. A. (2004). Reflecting on development of interpretative phenomenological analysis and its contribution to qualitative research in psychology. Qualitative Research in Psychology, 1, 39-54.

Smith, J. A., Flowers, P., \& Larkin, M. (2009). Interpretative phenomenological analysis: Theory, method, and research. London: Sage Publication Ltd.

Zeeshan, M. \& Aslam, N. (2013). Resilience and psychological wellbeing among congenitally blind, late blind and sighted individuals. Peak Journals, 1(1), 1-7.

Zhong, B., Li, W., Liu, X., Huang, X., Dai, X., Hu, Q., Zhang, H., \& Xu, H. (2013). Depressive symptoms among the visually disabled in Wuhan: An epidemiological survey. Shanghai Archives of Psychiatry, 25(5), 306-313. 